\title{
Can Zn Be a Critical Element in COVID-19 Treatment?
}

\author{
Mohammad Tariqur Rahman ${ }^{1}$ (D) $\cdot$ Syed Zahir Idid ${ }^{2}$
}

Received: 7 April 2020 / Accepted: 10 May 2020 / Published online: 26 May 2020

(C) Springer Science+Business Media, LLC, part of Springer Nature 2020

\begin{abstract}
The current COVID-19 pandemic caused by SARS-CoV-2 has prompted investigators worldwide to search for an effective antiviral treatment. A number of anti-viral drugs such as ribavirin, remdesivir, lopinavir/ritonavir, antibiotics such as azithromycin and doxycycline, and anti-parasite such as ivermectin have been recommended for COVID-19 treatment. In addition, sufficient pre-clinical rationale and evidence have been presented to use chloroquine for the treatment of COVID-19. Furthermore, $\mathrm{Zn}$ has the ability to enhance innate and adaptive immunity in the course of a viral infection. Besides, $\mathrm{Zn}$ supplement can favour COVID19 treatment using those suggested and/or recommended drugs. Again, the effectiveness of $\mathrm{Zn}$ can be enhanced by using chloroquine as an ionophore while $\mathrm{Zn}$ inside the infected cell can stop SARS-CoV-2 replication. Given those benefits, this perspective paper describes how and why $\mathrm{Zn}$ could be given due consideration as a complement to the prescribed treatment of COVID-19.
\end{abstract}

Keywords Anti-viral drugs $\cdot$ Chloroquine $\cdot \mathrm{SARS}-\mathrm{CoV}-2 \cdot$ RNA dependent RNA polymerase $\cdot$ Zinc transporter $\cdot$ Pneumocytes

\section{Introduction}

Coronaviruses $(\mathrm{CoV})$, named after its crown-like appearance under electron microscope, were known to cause severe acute respiratory syndrome coronavirus (SARS-CoV) and Middle East respiratory syndrome coronavirus (MERS-CoV) diseases with high mortality rate [1]. On March 11, 2020, the World Health Organization (WHO) declared Coronavirus Disease 2019 (COVID-19) outbreak as pandemic caused by another member of the Coronaviridae family - SARS-CoV-2.

SARS-CoV-2 primarily infects cells of the small air sacs known as alveoli consisting of alveolar cells and alveolar macrophages. There are two types of alveolar cells (type I and II) which are also known as pneumocytes. Type I cells provide $95 \%$ of the surface area of each alveoli and are flat hence are named squamous epithelial cells. Type II cells generally cluster in the corners of the

Mohammad Tariqur Rahman

m.tariqur.rahman@gmail.com; tarique@um.edu.my

Syed Zahir Idid

syedzahir@iium.edu.my; szidid@gmail.com

1 Faculty of Dentistry, University of Malaya, 50603 Kula Lumpur, Malaysia

2 Faculty of Allied Health Sciences, International Islamic University Malaysia, 25200 Kuantan, Malaysia alveoli and have a cuboidal shape. Infection by the SARS-CoV-2 causes an inflammatory condition also known as pneumonia affecting primarily alveoli [2]. Typically, symptoms include a combination of non-productive or dry cough, chest pain, fever, and difficulty in breathing. The pneumonic condition in COVID-19 is severe and is associated with its high mortality $[3,4]$.

The current COVID-19 pandemic caused by SARS-CoV-2 has prompted policy makers to take actions to prevent further spread of the virus. The same crisis also made investigators worldwide to search for an effective anti-viral treatment. The current review paper will highlight the potential of $\mathrm{Zn}$ supplement with the ongoing treatment modalities for COVID-19 patients. To start with, the paper will first briefly describe the virus and its mechanism of replication in the host cells (generally that is the pneumocytes of the lungs). A brief description will be added to highlight the changes in the host immune responses upon SARS-CoV-2 infection. Subsequently, a summary of the ongoing and recommended treatments will be presented. Finally, the paper will highlight how $\mathrm{Zn}$ can contribute to fight the battle with the SARS-CoV-2.

\section{The SARS-COV-2 Virus and Its Replication in Host Pneumocytes (Cells of the Lungs)}

SARS-CoV-2 is one of the seven types of coronavirus that are known to infect humans [4]. Based on the genetic properties, 
coronaviruses are grouped into four genera: $\alpha-\mathrm{CoV}, \beta-\mathrm{CoV}$, $\gamma-\mathrm{CoV}$, and $\delta-\mathrm{CoV}$ [2], and the COVID-19 belongs to $\beta-\mathrm{CoV}$ [4]. Like other coronaviruses, SARS-CoV-2 is also an enveloped virus with a single-strand, positive-sense RNA genome [5].

At the beginning of the replicative cycle, the polycistronic viral genome uses a unique transcription mechanism to generate a nested set of subgenomic (sg) mRNAs after entry and uncoating inside the host cell. Using the 5'-proximal open reading frames (ORFs) of the genome, namely ORF1a and ORF1b, two large replicase polyproteins (ppla and pplab) are translated. Eventually, 16 non-structural proteins (NSP) producing mature replicase proteins are released from ppla and pplab attributed to the proteolytic cleavages by ORF1aencoded proteases. The replicase proteins have a variety of functions that are required for viral RNA synthesis and capping, such as the RNA-dependent RNA polymerase (RdRp; NSP12), a helicase (NSP13), RNA cap-modifying methyltransferases (NSP14 and NSP16), and an exoribonuclease (NSP14). Using the host proteins, the coronavirus NSPs form membrane-associated replication and transcription complexes for viral membrane structures. For detail of the functions of each protein, please see the review by Cheng et al. [6].

Along with 16 non-structural proteins (NSPs) and four major structural proteins, namely spike (S), envelope (E), membrane (M), and nucleocapsid (N), SARS-CoV-2 contains eight accessory proteins [7]. The spike proteins have an S1 domain which is responsible for receptor binding and an S2 domain responsible for cell membrane fusion. In other words, S glycoproteins aid binding of the virus to the host cells. The receptor binding domain (RBD) of $\beta-\mathrm{CoV}$ is commonly located in the C-terminal domain of S1 [8]. The SARS-CoV-2 spike proteins were found to have 10- to 20-fold higher binding affinity to human angiotensin-converting enzyme 2 (ACE2) receptors than SARS-CoV does [9].

Using spike glycoproteins (S-glycoproteins), the SARS$\mathrm{CoV} 2$ binds to human angiotensin-converting enzyme 2 (ACE2) receptors expressed on pneumocytes [10]. Notably, ACE2 receptors are widely expressed on the epithelial cells of alveoli, trachea, bronchi, bronchial serous glands [11], and alveolar monocytes and macrophages [12].

Binding to ACE2 receptors triggers conformational changes in the S-glycoprotein allowing cleavage by the transmembrane protease-serine 2 of the S-glycoprotein. The virus is then transported into the cytoplasm through a mechanism called endocytosis. The low $\mathrm{pH}$ inside the endosomes favours the host protease cathepsin-L to cleave the S-glycoprotein. This results in the fusion of the viral envelope and endosomal phospholipidic membrane to release the positive-strand viral genomic RNA (+RNA) into the cell cytoplasm.

Like other RNA viruses, SARS-CoV-2 genome-encoded RNA-dependent RNA polymerase ( $R d R p)$ is central to SARS-CoV-2 replicative cycle. Initially, a polyprotein precursor is formed from which the RdRp-containing subunit is proteolytically cleaved. Subsequently, the RdRp is integrated into a membrane associated viral enzyme complex that drives the synthesis of negative-strand RNA [13, 14]. The negative RNA strand is used as a template for the synthesis of viral mRNA (Fig. 1). SARS-CoV-2, MERS-CoV, and SARS-CoV have remarkably similar sequences and encode structurally similar RdRp [15]. The RdRp has a deep groove as an active site for the polymerization of RNA.

Infected cells contain between 10 and 100 times more +RNA strands than -RNA strands. The polycistronic ribosome machinery of the infected cell synthesizes nonstructural proteins of the SARS-CoV-2 and assembles these into the replicase-transcriptase complex to favour viral subgenomic mRNA synthesis. Following replication, the envelope proteins are translated and inserted into the endoplasmic reticulum of the host cells to finally enter into the Golgi compartment. Consequently, the viral genomic RNA is packaged into the nucleocapsid and then envelope proteins are incorporated during the budding step to form mature virions. The $\mathrm{M}$ protein plays an essential role during viral assembly by interacting with the other proteins of the virus. Following assembly, the newly formed viral particles are transported to the cell surface in vesicles and are released by exocytosis. A number of detailed reviews have summarized the replication and the assembly of the virus $[13,16]$.

\section{Changes in Immune Response in COVID-19 Patients}

Immunological profiles of COVID-19 patients seem to vary widely. In general, COVID-19 patients were shown to have normal or lower white blood cell counts, lymphopenia, or thrombocytopenia, with an increased C-reactive protein level $[3,8,17-21]$. In vitro studies of SARS-CoV infection of respiratory epithelial cells, dendritic cells (DCs), showed delayed release of cytokines and chemokines at the early stages. However, higher secretion anti-viral cytokines such as interferons (IFNs) and proinflammatory cytokines such as interleukins (IL) IL-1 $\beta$, IL-6, and tumour necrosis factor (TNF)) and chemokines (C-C motif chemokine ligand CCL-2, CCL3 , and CCL-5) were recorded in the later stages [22-24].

In a retrospective, single-centre study, involving 99 COVID-19 patients treated in Wuhan Jinyintan Hospital, increased concentrations of C-reactive protein, IL-6, and serum ferritin were recorded along with an increased erythrocyte sedimentation rate [19]. The same group of patients also showed an increased number of neutrophils with decreased number of lymphocytes. Similar phenomena were observed with cytokine storms, with an overproduction of IL-7, IL-10, GCSF, IP10, MCP1, MIP1A, and TNF- $\alpha[3,17]$. 


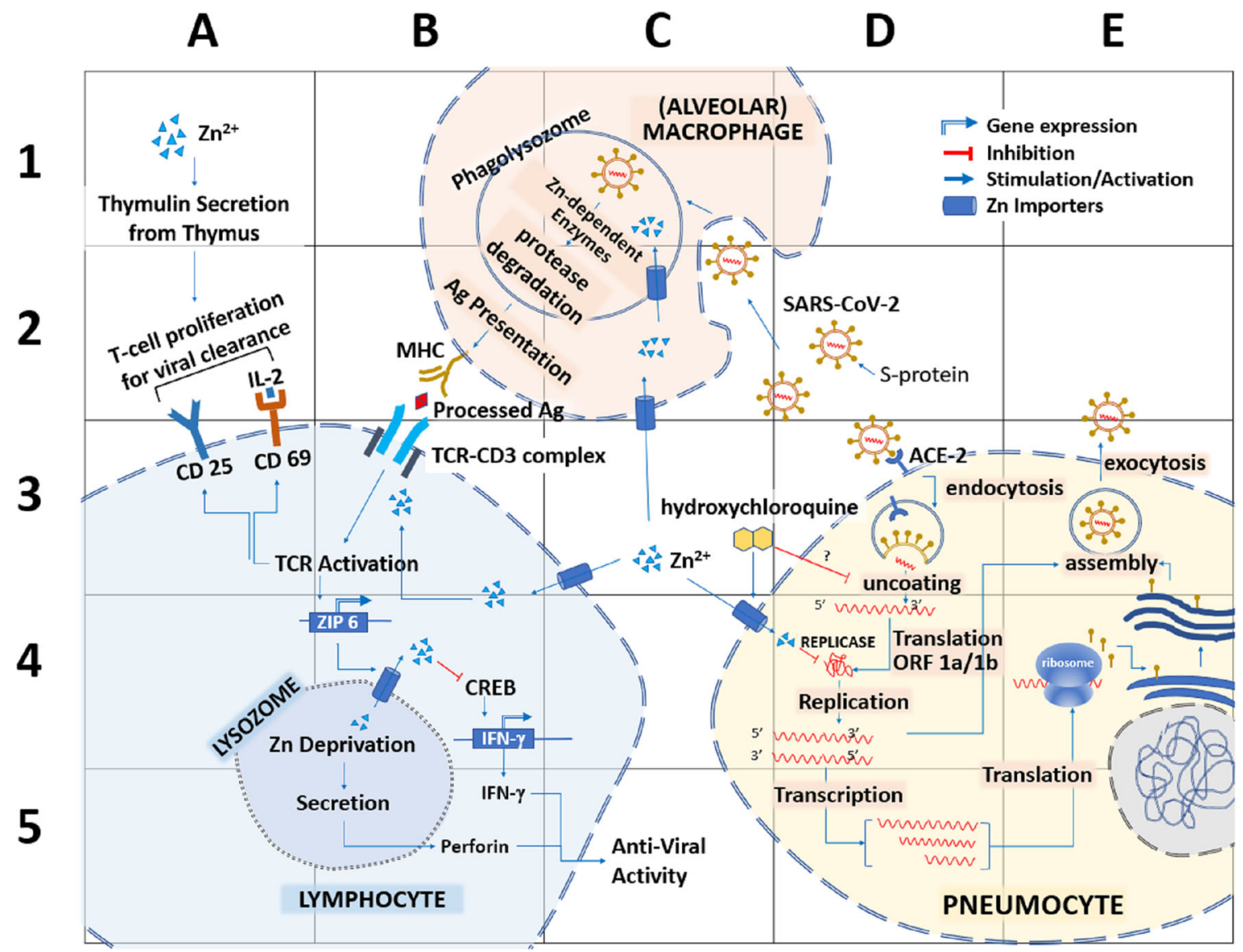

Fig. 1 Potential sites of action of $\mathrm{Zn}$ to counter SARS-CoV-2 in pneumocytes. SARS-CoV uses spike (S) proteins to bind to angiotensin-converting enzyme 2 (ACE2) on pneumocytes (D3). Virus enters the host cell through endocytosis and releases therein the viral RNA (D3). The replicase enzyme complex is translated from the viral genome that mediates both replication and transcription (D4). Virions are shed from the infected cell through exocytosis (E3). The primary site of $\mathrm{Zn}^{2+}$ could be the inactivation of the viral replicase (D4). At the same time, the additional $\mathrm{Zn}$ supplement might initiate interferon-( $($ ) (a common anti-viral agent) production by $\mathrm{T}$ lymphocytes (B5). However, $\mathrm{Zn}$ deprivation in the lysosome of the lymphocytes triggers to secrete perforin, which also exert anti-viral activity (B5). A pool of Zn importing inside the T lymphocytes activates $\mathrm{T}$ cell receptors as well as CD25 and CD69 to aid T cell proliferation and stabilization (A2-3). Added $\mathrm{Zn}$ also contributes to the production of thymulin from the thymus and triggers $\mathrm{T}$ lymphocyte production (A1-2). In alveolar macrophages, $\mathrm{Zn}$ can help to degrade the phagocytosed viral particle by the enzymes of the phagolysosome (B-C2). That in turn will help to present the processed An by the major histocompatibility complex (MHC) (B2)

higher. Furthermore, a high level of lymphocytes was found as a predictive better outcome $(\mathrm{OR}=0.10, P<0.001)$ for the patients who recovered [26].

\section{Zn Regulation in Human Cells}

Zinc is widely distributed in human tissues, where virtually all $\mathrm{Zn}$ is present in intracellular compartments such as the nucleus (30-40\%), cytosol, and other organelles and specialized vesicles $(50 \%)$, and the rest is bound with cell membrane proteins [27]. While cells need a constant supply of $\mathrm{Zn}$, free $\mathrm{Zn}$ ions $\left(\mathrm{Zn}^{2+}\right)$ can be toxic to the cells by inhibiting cytoplasmic enzymes such as adenylate cyclase [28].

In humans, plasma $\mathrm{Zn}$ level is maintained between 10 and $18 \mathrm{~mol} / \mathrm{L}$ representing $0.1 \%$ of total body $\mathrm{Zn}$ [29]. The total zinc content that favours a typical fibroblast-like cell to grow 
in ordinary culture media is $\sim 0.25 \mathrm{fmol}$ per cell or $\sim 200 \mu \mathrm{M}$. However, in vitro growth of the cells stops at cellular zinc levels below $\sim 0.2 \mathrm{fmol}$ per cell [30].

The intracellular homeostasis of $\mathrm{Zn}$ as well as exchange of $\mathrm{Zn}$ in and out of the cells is controlled by a large number of proteins belonging to two $\mathrm{Zn}$ transporter protein families, SLC39A (Zn importer protein, i.e. ZIP and ZRT/IRT-related protein, 14 ZIP) and SLC30A (Zn Transporter, i.e. ZnT, 10 ZnTs) [31]. ZnTs generally transport $\mathrm{Zn}^{2+}$ out of the cytosol, whereas ZIPs import them from cellular compartments or the extracellular space into the cytosol [32, 33]. Most ZnTs are present in intracellular compartments, such as endosomes, Golgi, or endoplasmic reticulum while only ZnT1 appears to be located at the plasma membrane as it is the primary regulator of cellular Zn efflux [30]. Most ZIPs are observed at the plasma membrane; however, Zip7 is located at the Golgi apparatus [34].

\section{Zinc in Host Immune Mechanisms}

Unlike other "first row" transition metals/elements, $\mathrm{Zn}$ does not participate in redox reactions but rather functions as a Lewis acid to accept a pair of electrons. This property makes $\mathrm{Zn}^{2+}$ a stable ion in a biological medium and an ideal metal cofactor for reactions that require a redox-stable ion such as proteolysis and the hydration of carbon dioxide. Metallothioneins-a cysteine-rich low molecular weight group of proteins - act as reservoir of the intracellular concentration of free $\mathrm{Zn}^{2+}$ [35-37]. Hence, $\mathrm{Zn}^{2+}$ can serve as intracellular second messenger and may trigger apoptosis or a decrease in protein synthesis at elevated concentrations [38-40].

A number of immunome activation pathways are activated by $\mathrm{Zn}$ such as NF- $\mathrm{KB}$ signalling pathway. NF- $\mathrm{kB}$ influences the expression of pro-inflammatory cytokines, namely IL-1b, IL-6, IL-8, TNF- $\alpha$, and MCP-1, chemokines, acute phase proteins (CRP and fibrinogen), matrix metalloproteinases, adhesion molecules, growth factors, and other factors involved in inflammatory response, such as COX-2 and iNOS [41, 42].

Zinc administration in mixed lymphocyte cultures was shown to induce and stabilize $\mathrm{CD} 4^{+} \mathrm{CD} 25^{+} \mathrm{Foxp} 3^{+}$and $\mathrm{CD} 4^{+} \mathrm{CD} 25^{+} \mathrm{CTLA}-4^{+} \mathrm{T}$ cells. These effects were attributed to zinc-induced upregulation of Foxp3 and KLF-10 and downregulation of IRF-1 whereas in resting lymphocytes zinc increases IRF-1 [43]. It is important to note that the number of CD4+ and CD8+ T cells is critical in anti-viral immunity [44, 45].

On the other hand, $\mathrm{Zn}$ depletion can cause a significant suppression of autophagy in cells (human hepatoma cells VL-17A). Conversely, in vitro $\mathrm{Zn}$ addition stimulated autophagy in the same cells. Thus, a critical role of $\mathrm{Zn}$ was suggested in autophagy under basal conditions [46]. In various pathological conditions including viral infection, autophagy plays an important protective role as host defence mechanism [47-49]. In autophagy, the intracellular components such as protein aggregates and damaged organelles are engulfed into a double-membrane structure called autophagosome and fuse with lysosome to form autolysosome to degrade the engulfed components using lysosomal enzymes [50, 51]. Lysosome contains more than 50 enzymes, including proteases, peptidases, phosphatases, nucleases, glycosidases, sulfatases, and lipases [52]. Essentially, the structural and functional integrity of many of these enzymes depends on $\mathrm{Zn}$ [53].

\section{Immune Regulation of Zinc in Viral Infection}

In vitro studies involving added $\mathrm{Zn}^{2+}$ in the presence of its cellular import stimulatory compounds, such as hinokitiol (HK), pyrrolidine dithiocarbamate (PDTC), and pyrithione (PT), were shown to inhibit the replication of various RNA viruses, including influenza virus [54], respiratory syncytial virus [55], and several picornaviruses [56-58]. These reports suggested inhibition of intracellular $\mathrm{Zn}^{2+}$ in the replicative cycle of these viruses. More particularly, $\mathrm{Zn}^{2+}$ was shown to inhibit polyprotein processing in cells infected with human rhinovirus and coxsackievirus $\mathrm{B} 3$ [58].

In addition to SARS-CoV, a number of other viruses, including HIV, HSV, and vaccinia virus, are known to be inhibited by $\mathrm{Zn}$ salts. $\mathrm{Zn}$ is known to inhibit the viral entry, blocking of polyprotein processing, or inhibition of viral RdRp activity [59-61]. Using Huh7 cells transfected with in vitro synthesized capped genomic RNA of a g-1 HEV, Kaushik et al. [62] showed that $\mathrm{Zn}$ but not Mg salts, namely $\mathrm{Zn}$-sulfate and $\mathrm{Zn}$-acetate, can inhibit viral sense and antisense RNA levels by approximately $50 \%$ at a working concentration of $10 \mu \mathrm{M}$. Thus, $\mathrm{Zn}$ salts were shown to directly inhibit the activity of viral RdRp thus inhibiting viral replication.

\section{Recommended and Ongoing Treatments for COVID-19}

The suggested treatments for COVID-19 are, but not limited to, the use of (i) convalescent plasma for COVID-19 treatment [63-65]; (ii) ribavirin, a nucleoside analogue in combination with recombinant interferon showed inhibition of MERSCoV replication [66]; (iii) lopinavir/ritonavir - a combination of a protease inhibitor and a booster used for the treatment of human immunodeficiency virus infection [67]; (iv) remdesivir, a nucleotide analogue that inhibit RNA polymerase with a broad spectrum of anti-viral activities; in inhibition of human and zoonotic coronavirus [15, 68, 69]; (v) favipiravir (also known as T-705, Avigan or favilavir) is a pyrazinecarboxamide derivative known to inhibit RNA polymerase [70]. In addition, azithromycin and doxycycline- 
commonly used antibiotics to inhibit viral replication and IL-6 production [71] and drugs that suppress IL-1 or IL-1R [72] were also suggested for the treatment and prevention of COVID-19 disease.

As of April 21, 2020, more than 500 clinical trials have been registered at the various international and national clinical trial registry sites [73]. The efficacy of a number of recommended anti-viral drugs has been investigated with various outcomes. Such randomized clinical trials on lopinavirritonavir did not show any benefit beyond standard care [74]; favipiravir, compared with Arbidol, did not significantly improve the clinical recovery rate at day 7 [75]. Besides, hydroxychloroquine versus hydroxychloroquine combined with azithromycin was investigated following nonrandomized trials [76]. Other ongoing clinical trials include IL-6 inhibitors (tocilizumab and sarilumab), convalescent plasma therapy, stem-cell transfusion, candidate vaccines, and traditional Chinese medicines.

In a systematic review, Cortegiani et al. [77] argued that "there is sufficient pre-clinical rationale and evidence regarding the effectiveness of chloroquine for treatment of COVID19 as well as evidence of safety from long-time use in clinical practice for other indications." Chloroquine was shown to inhibit in vitro replication of SARS-CoV-2 in Vero E6 cells in an effective concentration $\mathrm{EC}_{90}$ of $6.90 \mu \mathrm{M}$ that can be easily achieved with standard dosing, due to its favourable penetration into tissues, including in the lung [68]. This is substantially lower than the concentration detected in human plasma when the drug is prescribed to treat malaria at a dose of $25 \mathrm{mg} / \mathrm{kg}$ over 3 days [78]. However, for COVID-19 patients, a lower dose such as $3.6 \mathrm{mg} / \mathrm{kg}$ that are often prescribed to treat rheumatoid arthritis has been suggested for long-term prophylaxis as the dose is similar to IC50 for SARS-CoV $[78,79]$. It is to be noted that hydroxychloroquine showed greater efficacy than chloroquine, at least based on in vitro studies [80]. Besides, hydroxychloroquine was shown to have minimal risk of toxicity such as retinopathy [81]. Other recent studies also showed that hydroxychloroquine is a less toxic metabolite of chloroquine, as it is more soluble, and causes less side effects and therefore is safer [76, 80, 82, 83].

It has been hypothesized that both hydroxychloroquine and chloroquine can interfere with ACE2 receptor glycosylation and prevents SARS-CoV-2 binding to pneumocytes. Chloroquine could also possibly inhibit sialic acid biosynthesis thus limiting cell surface binding of SARS-CoV-2. In case the viral particle is endocytosed, chloroquine has been hypothesized to modulate the acidification of endosomes thereby inhibiting formation of the autophagosome. Through reduction of cellular mitogenactivated protein (MAP) kinase activation, chloroquine may also inhibit virus replication. Moreover, chloroquine could alter $M$ protein maturation and interfere with virion assembly and budding [16].
It is to be noted that both chloroquine and hydroxychloroquine are weak bases present in protonated form in the extracellular environment hence are incapable of crossing the plasma membrane. In the non-protonated form, chloroquine and hydroxychloroquine may enter the intracellular compartments and gradually become protonated according to the Henderson-Hasselbach law. This conversion allows both chloroquine and hydroxychloroquine to reside in acidic organelles such as the endosome, Golgi vesicles, and the lysosomes. [84].

\section{Why Is Zn Critical for COVID-19 Treatment?}

\section{Zn Can Enhance Cell-Mediated and Adaptive Immunity in the Course of Infection}

Zinc is thoroughly involved in cell-mediated immunity against any infectious agent such as bacteria and virus. Zinc is one of the major factors that control function and proliferation of neutrophils, NK cells, macrophages, and T and B lymphocytes as well as cytokine production by the immune cells. $\mathrm{Zn}$ also mediates protection from the adverse effect of ROS that are generally produced during inflammatory processes. Free intracellular $\mathrm{Zn}^{2+}$ is essential in extravasation to the site of the infection and uptake and killing of microorganisms by neutrophils [85]. For more detail on the functions of $\mathrm{Zn}$ in immunity, please see the review articles by [86-89].

\section{Augmented Effect of $\mathrm{Zn}$ and Chloroquine to Stop SARS-CoV-2 Replication}

Chloroquine was known to increase vacuolar $\mathrm{pH}$ when trapped in acidic organelles, such as lysosomes. This increase in $\mathrm{pH}$ disrupts lysosomal acidification leading to the impairment of autophagosome fusion and autophagic degradation $[90,91]$. Using human ovarian carcinoma cell line A2780, Xue J. et al. [92] reported that chloroquine can act as ionophore for $\mathrm{Zn}$. Chloroquine enhances uptake of $\mathrm{Zn}$ by the lysosomes, and the combination of $\mathrm{Zn}$ and chloroquine enhances chloroquine cytotoxicity and induces apoptosis in malignant cells. In their experiment [92], A2780 ovarian cancer cells were treated with $100-300 \mu \mathrm{M}$ chloroquine in the presence of increased concentrations of $\mathrm{ZnCl}_{2}$ for $1 \mathrm{~h}$. Intracellular basal $\mathrm{Zn}$ levels were barely detectable in control cells without any chloroquine. However, chloroquine addition to the culture medium caused significant increases of intracellular $\mathrm{Zn}$ in a dose-dependent manner.

\section{Zn Can Directly Inhibit SARS-CoV-2 Replication}

Using recombinant SARS-CoV nsp12, te Velthuis et al. [61] showed that $\mathrm{Zn}^{2+}$ directly inhibited the in vitro $\mathrm{RdRp}$ activity 
(Fig. 1). They also reported that specifically, $\mathrm{Zn}^{2+}$ was found to inhibit the SARS-CoV RdRp elongation and template binding. Earlier, it was also shown that $\mathrm{Zn}^{2+}$ inhibited the proteolytic processing of replicase polyproteins [93, 94].

\section{Zn Enhances Efficiency of Anti-viral Drugs}

A number of anti-viral drugs such as ribavirin, remdesivir, lopinavir/ritonavir, and antibiotics such as azithromycin and doxycycline have been recommended for the treatment of COVID-19. Zn supplement can favour COVID-19 treatment using some of these anti-viral drugs.

Zinc supplementation was suggested as a complementary therapy in chronic hepatitis $C$ patients to increase the tolerance to IFN- $\alpha-2 \mathrm{a}$ and ribavirin [95]. However, a 24-week Zn supplementation reduced the incidence of abdominal discomfort without any additive effect on the anti-hepatitis $\mathrm{C}$ virus dual therapy of IFN- $\alpha-2$ and ribavirin [96].

While evaluating the impact of $\mathrm{ZnSO}_{4}$ supplementation in HIV-infected individuals, the supplement was found useful in management of atazanavir-ritonavir-related unconjugated hyperbilirubinemia in selected patients [67].

\section{Zinc Supplement: Limits and Risks}

Zinc as an adjuvant therapy can be prescribed in different forms of Zn salt, such as Zn-gluconate, Zn-acetate, Zn-sulfate, and $\mathrm{Zn}$-picolinate. However, the amount of elemental $\mathrm{Zn}$ in each salt varies. For example, $\mathrm{Zn}$-sulfate contains about $23 \%$ elemental $\mathrm{Zn}$; therefore, to have $50 \mathrm{mg}$ of $\mathrm{Zn}$, a $220 \mathrm{mg}$ of $\mathrm{Zn}$ sulfate tablet would be required for consumption. It is important to note that the recommended daily allowance of $\mathrm{Zn}$ will vary according to the age, sex, and health conditions of an individual. For healthy adults, the recommended daily allowance is typically $15-30 \mathrm{mg}$ of elemental $\mathrm{Zn}$. Despite the beneficial effects of $\mathrm{Zn}$ in immune response, long-term high-dose $\mathrm{Zn}$ consumption will cause a decrease of high-density lipoprotein cholesterol levels, anaemia, copper deficiency, and possible genitourinary complications [97].

\section{Conclusion}

Zinc plays crucial roles in many aspects of life. In the course of infection, the immunomodulatory role of $\mathrm{Zn}$ is well evident. In the current pandemic of SARS-CoV-2, $\mathrm{Zn}$ supplement could play an important role to treat COVID-19 patients such as (i) added immune boosting effects with anti-viral drugs and (ii) stopping SARS-CoV-2 replication in infected cells, if combined with chloroquine. In view of this discussion, oral $\mathrm{Zn}$ supplement can be given using a suitable form of $\mathrm{Zn}$-salt.
Authors' Contributions SZI and MTR conceptualize the idea. MTR prepared the initial draft. SZI and MTR revised the manuscript.

Data Availability I have not used any data that are required to be available for the readers.

\section{Compliance with Ethical Standards}

Conflict of Interest The authors declare that they have no competing interests.

Ethics Approval Not applicable.

Consent to Participate (Include Appropriate Statements) Not applicable.

Code Availability Not applicable.

\section{References}

1. Hui DS, Memish ZA, Zumla A (2014) Severe acute respiratory syndrome vs. the Middle East respiratory syndrome. Curr Opin Pulm Med 20:233-241. https://doi.org/10.1097/MCP. 0000000000000046

2. Su S, Wong G, Shi W, Liu J, Lai ACK, Zhou J, Liu W, Bi Y, Gao GF (2016) Epidemiology, genetic recombination, and pathogenesis of coronaviruses. Trends Microbiol 24:490-502. https://doi.org/10. 1016/j.tim.2016.03.003

3. Huang C, Wang Y, Li X et al (2020) Clinical features of patients infected with 2019 novel coronavirus in Wuhan, China. Lancet 395:497-506. https://doi.org/10.1016/S0140-6736(20)30183-5

4. Zhu N, Zhang D, Wang W, Li X, Yang B, Song J, Zhao X, Huang B, Shi W, Lu R, Niu P, Zhan F, Ma X, Wang D, Xu W, Wu G, Gao GF, Tan W, China Novel Coronavirus Investigating and Research Team (2020) A novel coronavirus from patients with pneumonia in China, 2019. N Engl J Med 382:727-733. https://doi.org/10.1056/ NEJMoa2001017

5. Forni D, Cagliani R, Clerici M, Sironi M (2017) Molecular evolution of human coronavirus genomes. Trends Microbiol 25:35-48. https://doi.org/10.1016/j.tim.2016.09.001

6. Cheng VCC, Lau SKP, Woo PCY, Yuen KY (2007) Severe acute respiratory syndrome coronavirus as an agent of emerging and reemerging infection. Clin Microbiol Rev 20:660-694. https://doi. org/10.1128/CMR.00023-07

7. Wu A, Peng Y, Huang B, Ding X, Wang X, Niu P, Meng J, Zhu Z, Zhang Z, Wang J, Sheng J, Quan L, Xia Z, Tan W, Cheng G, Jiang $\mathrm{T}$ (2020) Genome composition and divergence of the novel coronavirus (2019-nCoV) originating in China. Cell Host Microbe 27: 325-328. https://doi.org/10.1016/j.chom.2020.02.001

8. Lu R, Zhao X, Li J et al (2020) Genomic characterisation and epidemiology of 2019 novel coronavirus: implications for virus origins and receptor binding. Lancet 395:565-574. https://doi.org/ 10.1016/S0140-6736(20)30251-8

9. Wrapp D, Wang N, Corbett KS, Goldsmith JA, Hsieh CL, Abiona O, Graham BS, McLellan JS (2020) Cryo-EM structure of the 2019-nCoV spike in the prefusion conformation. Science 367: 1260-1263. https://doi.org/10.1126/science.abb2507

10. Ou X, Liu Y, Lei X, Li P, Mi D, Ren L, Guo L, Guo R, Chen T, Hu J, Xiang Z, Mu Z, Chen X, Chen J, Hu K, Jin Q, Wang J, Qian Z (2020) Characterization of spike glycoprotein of SARS-CoV-2 on virus entry and its immune cross-reactivity with SARS-CoV. Nat Commun 11:1620. https://doi.org/10.1038/s41467-020-15562-9 
11. Liu L, Wei Q, Alvarez X, Wang H, du Y, Zhu H, Jiang H, Zhou J, Lam P, Zhang L, Lackner A, Qin C, Chen Z (2011) Epithelial cells lining salivary gland ducts are early target cells of severe acute respiratory syndrome coronavirus infection in the upper respiratory tracts of rhesus macaques. J Virol 85:4025-4030. https://doi.org/10. 1128/JVI.02292-10

12. Kuba K, Imai Y, Rao S, Gao H, Guo F, Guan B, Huan Y, Yang P, Zhang Y, Deng W, Bao L, Zhang B, Liu G, Wang Z, Chappell M, Liu Y, Zheng D, Leibbrandt A, Wada T, Slutsky AS, Liu D, Qin C, Jiang C, Penninger JM (2005) A crucial role of angiotensin converting enzyme 2 (ACE2) in SARS coronavirus-induced lung injury. Nat Med 11:875-879. https://doi.org/10.1038/nm1267

13. Fehr AR, Perlman S (2015) Coronaviruses: an overview of their replication and pathogenesis. Methods Mol Biol 1282:1-23. https:// doi.org/10.1007/978-1-4939-2438-7_1

14. Perlman S, Netland J (2009) Coronaviruses post-SARS: update on replication and pathogenesis. Nat Rev Microbiol 7:439-450. https://doi.org/10.1038/nrmicro2147

15. Morse JS, Lalonde T, Xu S, Liu WR (2020) Learning from the past: possible urgent prevention and treatment options for severe acute respiratory infections caused by $2019-\mathrm{nCoV}$. Chembiochem 21: 730-738. https://doi.org/10.1002/cbic.202000047

16. Devaux CA, Rolain J-M, Colson P, Raoult D (2020) New insights on the antiviral effects of chloroquine against coronavirus: what to expect for COVID-19? Int J Antimicrob Agents 105938:105938. https://doi.org/10.1016/j.ijantimicag.2020.105938

17. Lescure F-X, Bouadma L, Nguyen D, Parisey M, Wicky PH, Behillil S, Gaymard A, Bouscambert-Duchamp M, Donati F, le Hingrat Q, Enouf V, Houhou-Fidouh N, Valette M, Mailles A, Lucet JC, Mentre F, Duval X, Descamps D, Malvy D, Timsit JF, Lina B, van-der-Werf S, Yazdanpanah Y (2020) Clinical and virological data of the first cases of COVID-19 in Europe: a case series. Lancet Infect Dis. https://doi.org/10.1016/S1473-3099(20)30200-0

18. Zhou M, Zhang X, Qu J (2020) Coronavirus disease 2019 (COVID-19): a clinical update. Front Med. https://doi.org/10. 1007/s11684-020-0767-8

19. Chen N, Zhou M, Dong X et al (2020) Epidemiological and clinical characteristics of 99 cases of 2019 novel coronavirus pneumonia in Wuhan, China: a descriptive study. Lancet 395:507-513. https:// doi.org/10.1016/S0140-6736(20)30211-7

20. Ma HY, Li H, Wang JC, Xu FS (2006) Expression and significance of metallothionein in the placenta of women with low level lead exposure during pregnancy. Zhonghua Fu Chan Ke Za Zhi 41(10): 676-679

21. Ye Q, Wang B, Mao J (2020) The pathogenesis and treatment of the 'cytokine storm' in COVID-19. J Inf Secur. https://doi.org/10.1016/ j.jinf.2020.03.037

22. Law HKW, Cheung CY, Ng HY, Sia SF, Chan YO, Luk W, Nicholls JM, Peiris JSM, Lau YL (2005) Chemokine upregulation in SARS-coronavirus-infected, monocyte-derived human dendritic cells. Blood 106:2366-2374. https://doi.org/10. 1182/blood-2004-10-4166

23. Cheung CY, Poon LLM, Ng IHY, Luk W, Sia SF, Wu MHS, Chan KH, Yuen KY, Gordon S, Guan Y, Peiris JSM (2005) Cytokine responses in severe acute respiratory syndrome coronavirusinfected macrophages in vitro: possible relevance to pathogenesis. J Virol 79:7819-7826. https://doi.org/10.1128/JVI.79.12.78197826.2005

24. Pedersen SF, Ho Y-C (2020) SARS-CoV-2: a storm is raging. J Clin Invest 130:2202-2205. https://doi.org/10.1172/JCI137647

25. Wang Z, Yang B, Li Q, Wen L, Zhang R (2020) Clinical features of 69 cases with coronavirus disease 2019 in Wuhan. China Clin Infect Dis an Off Publ Infect Dis Soc Am. https://doi.org/10.1093/ cid/ciaa272

26. Wang L, He W, Yu X, Hu D, Bao M, Liu H, Zhou J, Jiang H (2020) Coronavirus disease 2019 in elderly patients: characteristics and prognostic factors based on 4-week follow-up. J Inf Secur. https:// doi.org/10.1016/j.jinf.2020.03.019

27. Vallee BL, Falchuk KH (1993) The biochemical basis of zinc physiology. Physiol Rev 73:79-118

28. Klein C, Heyduk T, Sunahara RK (2004) Zinc inhibition of adenylyl cyclase correlates with conformational changes in the enzyme. Cell Signal 16:1177-1185. https://doi.org/10.1016/j.cellsig. 2004.03.008

29. Foster M, Samman S (2012) Zinc and regulation of inflammatory cytokines: implications for cardiometabolic disease. Nutrients 4: 676-694. https://doi.org/10.3390/nu4070676

30. Palmiter RD, Findley SD (1995) Cloning and functional characterization of a mammalian zinc transporter that confers resistance to zinc. EMBO J 14:639-649

31. Lichten LA, Cousins RJ (2009) Mammalian zinc transporters: nutritional and physiologic regulation. Annu Rev Nutr 29:153-176. https://doi.org/10.1146/annurev-nutr-033009-083312

32. Cousins RJ, Liuzzi JP, Lichten LA (2006) Mammalian zinc transport, trafficking, and signals. J Biol Chem 281:24085-24089. https://doi.org/10.1074/jbc.R600011200

33. Aydemir TB, Blanchard RK, Cousins RJ (2006) Zinc supplementation of young men alters metallothionein, zinc transporter, and cytokine gene expression in leukocyte populations. Proc Natl Acad Sci U S A 103:1699-1704. https://doi.org/10.1073/pnas. 0510407103

34. Huang L, Kirschke CP, Zhang Y, Yu YY (2005) The ZIP7 gene (Slc39a7) encodes a zinc transporter involved in zinc homeostasis of the Golgi apparatus. J Biol Chem 280:15456-15463. https://doi. org/10.1074/jbc.M412188200

35. Pauwels M, van Weyenbergh J, Soumillion A et al (1994) Induction by zinc of specific metallothionein isoforms in human monocytes. Eur J Biochem 220:105-110

36. Kr zel A, Maret W (2007) Dual nanomolar and picomolar Zn (II) binding properties of metallothionein. J Am Chem Soc 129:1091110921. https://doi.org/10.1021/ja071979s

37. Rahman MT, Haque N, Abu Kasim NH, De Ley M (2017) Origin, function, and fate of metallothionein in human blood. Rev Physiol Biochem Pharmacol 173:41-62. https://doi.org/10.1007/112 2017 1

38. Alirezaei M, Nairn AC, Glowinski J, Prémont J, Marin P (1999) Zinc inhibits protein synthesis in neurons. Potential role of phosphorylation of translation initiation factor-2alpha. J Biol Chem 274: 32433-32438. https://doi.org/10.1074/jbc.274.45.32433

39. Frederickson CJ, Koh J-Y, Bush AI (2005) The neurobiology of zinc in health and disease. Nat Rev Neurosci 6:449-462. https://doi. org/10.1038/nrn1671

40. Lazarczyk M, Favre M (2008) Role of Zn2+ ions in host-virus interactions. J Virol 82:11486-11494. https://doi.org/10.1128/JVI. 01314-08

41. Lawrence $\mathrm{T}$ (2009) The nuclear factor NF-kappaB pathway in inflammation. Cold Spring Harb Perspect Biol 1:a001651. https://doi. org/10.1101/cshperspect.a001651

42. Hayden MS, Ghosh S (2014) Regulation of NF-kappaB by TNF family cytokines. Semin Immunol 26:253-266. https://doi.org/10. 1016/j.smim.2014.05.004

43. Maywald M, Rink L (2017) Zinc supplementation induces CD4(+ )CD25(+)Foxp3(+) antigen-specific regulatory $\mathrm{T}$ cells and suppresses IFN-gamma production by upregulation of Foxp3 and KLF-10 and downregulation of IRF-1. Eur J Nutr 56:1859-1869. https://doi.org/10.1007/s00394-016-1228-7

44. Whitmire JK, Ahmed R (2000) Costimulation in antiviral immunity: differential requirements for $\mathrm{CD} 4(+)$ and $\mathrm{CD} 8(+) \mathrm{T}$ cell responses. Curr Opin Immunol 12:448-455. https://doi.org/10.1016/ s0952-7915(00)00119-9

45. Jansen JM, Gerlach T, Elbahesh H, Rimmelzwaan GF, Saletti G (2019) Influenza virus-specific CD4+ and CD8+ T cell-mediated 
immunity induced by infection and vaccination. J Clin Virol 119: 44-52. https://doi.org/10.1016/j.jcv.2019.08.009

46. Liuzzi JP, Yoo C (2013) Role of zinc in the regulation of autophagy during ethanol exposure in human hepatoma cells. Biol Trace Elem Res 156:350-356. https://doi.org/10.1007/s12011-013-9816-3

47. Jiang P, Mizushima N (2014) Autophagy and human diseases. Cell Res 24:69-79. https://doi.org/10.1038/cr.2013.161

48. Choi AMK, Ryter SW, Levine B (2013) Autophagy in human health and disease. N Engl J Med 368:651-662. https://doi.org/ 10.1056/NEJMra1205406

49. Meijer AJ, Codogno P (2009) Autophagy: regulation and role in disease. Crit Rev Clin Lab Sci 46:210-240. https://doi.org/10.1080/ 10408360903044068

50. Mizushima N (2018) A brief history of autophagy from cell biology to physiology and disease. Nat Cell Biol 20:521-527. https://doi. org/10.1038/s41556-018-0092-5

51. Levine B, Kroemer G (2019) Biological functions of autophagy genes: a disease perspective. Cell 176:11-42. https://doi.org/10. 1016/j.cell.2018.09.048

52. Lubke T, Lobel P, Sleat DE (2009) Proteomics of the lysosome. Biochim Biophys Acta 1793:625-635. https://doi.org/10.1016/j. bbamcr.2008.09.018

53. Maret W (2013) Zinc biochemistry: from a single zinc enzyme to a key element of life. Adv Nutr 4:82-91. https://doi.org/10.3945/an. 112.003038

54. Uchide N, Ohyama K, Bessho T et al (2002) Effect of antioxidants on apoptosis induced by influenza virus infection: inhibition of viral gene replication and transcription with pyrrolidine dithiocarbamate. Antivir Res 56:207-217. https://doi.org/10.1016/s0166-3542(02) 00109-2

55. Suara RO, Crowe JEJ (2004) Effect of zinc salts on respiratory syncytial virus replication. Antimicrob Agents Chemother 48: 783-790. https://doi.org/10.1128/aac.48.3.783-790.2004

56. Korant BD, Kauer JC, Butterworth BE (1974) Zinc ions inhibit replication of rhinoviruses. Nature 248:588-590. https://doi.org/ $10.1038 / 248588 \mathrm{a} 0$

57. Lanke K, Krenn BM, Melchers WJG, Seipelt J, van Kuppeveld FJM (2007) PDTC inhibits picornavirus polyprotein processing and RNA replication by transporting zinc ions into cells. J Gen Virol 88:1206-1217. https://doi.org/10.1099/vir.0.82634-0

58. Krenn BM, Gaudernak E, Holzer B, Lanke K, van Kuppeveld FJM, Seipelt J (2009) Antiviral activity of the zinc ionophores pyrithione and hinokitiol against picornavirus infections. J Virol 83:58-64. https://doi.org/10.1128/JVI.01543-08

59. Katz E, Margalith E (1981) Inhibition of vaccinia virus maturation by zinc chloride. Antimicrob Agents Chemother 19:213-217. https://doi.org/10.1128/aac.19.2.213

60. Haraguchi Y, Sakurai H, Hussain S, Anner BM, Hoshino H (1999) Inhibition of HIV-1 infection by zinc group metal compounds. Antivir Res 43:123-133. https://doi.org/10.1016/s0166-3542(99) 00040-6

61. te Velthuis AJW, van den Worm SHE, Sims AC, Baric RS, Snijder EJ, van Hemert MJ (2010) $\mathrm{Zn}(2+)$ inhibits coronavirus and arterivirus RNA polymerase activity in vitro and zinc ionophores block the replication of these viruses in cell culture. PLoS Pathog 6: e1001176. https://doi.org/10.1371/journal.ppat.1001176

62. Kaushik N, Subramani C, Anang S, Muthumohan R, Shalimar, Nayak B, Ranjith-Kumar CT, Surjit M (2017) Zinc salts block hepatitis $\mathrm{E}$ virus replication by inhibiting the activity of viral RNA-dependent RNA polymerase. J Virol 91. https://doi.org/10. 1128/JVI.00754-17

63. Chen L, Xiong J, Bao L, Shi Y (2020) Convalescent plasma as a potential therapy for COVID-19. Lancet Infect Dis 20:398-400. https://doi.org/10.1016/S1473-3099(20)30141-9
64. Casadevall A, Pirofski L-A (2020) The convalescent sera option for containing COVID-19. J Clin Invest 130:1545-1548. https://doi. org/10.1172/JCI138003

65. Wong HK, Lee CK (2020) Pivotal role of convalescent plasma in managing emerging infectious diseases. Vox Sang. https://doi.org/ 10.1111/vox.12927

66. Falzarano D, de Wit E, Martellaro C, Callison J, Munster VJ, Feldmann H (2013) Inhibition of novel beta coronavirus replication by a combination of interferon-alpha $2 \mathrm{~b}$ and ribavirin. Sci Rep 3: 1686. https://doi.org/10.1038/srep01686

67. Moyle G, Else L, Jackson A, Back D, Yapa MH, Seymour N, Ringner-Nackter L, Karolia Z, Gazzard B, Boffito M (2013) Coadministration of atazanavir-ritonavir and zinc sulfate: impact on hyperbilirubinemia and pharmacokinetics. Antimicrob Agents Chemother 57:3640-3644. https://doi.org/10.1128/AAC.00357-13

68. Wang M, Cao R, Zhang L, Yang X, Liu J, Xu M, Shi Z, Hu Z, Zhong W, Xiao G (2020) Remdesivir and chloroquine effectively inhibit the recently emerged novel coronavirus (2019-nCoV) in vitro. Cell Res 30:269-271

69. Gordon CJ, Tchesnokov EP, Feng JY, Porter DP, Götte M (2020) The antiviral compound remdesivir potently inhibits RNAdependent RNA polymerase from Middle East respiratory syndrome coronavirus. J Biol Chem 295:4773-4779. https://doi.org/ 10.1074/jbc.AC120.013056

70. Furuta Y, Takahashi K, Shiraki K, Sakamoto K, Smee DF, Barnard DL, Gowen BB, Julander JG, Morrey JD (2009) T-705 (favipiravir) and related compounds: novel broad-spectrum inhibitors of RNA viral infections. Antivir Res 82:95-102. https://doi.org/10.1016/j. antiviral.2009.02.198

71. Sargiacomo C, Sotgia F, Lisanti MP (2020) COVID-19 and chronological aging: senolytics and other anti-aging drugs for the treatment or prevention of corona virus infection? Aging (Albany NY). https://doi.org/10.18632/aging.103001

72. Conti P, Gallenga CE, Tete $\mathrm{G}$ et al (2020) How to reduce the likelihood of coronavirus-19 (CoV-19 or SARS-CoV-2) infection and lung inflammation mediated by IL-1. J Biol Regul Homeost Agents 34

73. Thorlund K, Dron L, Park J et al (2020) Correspondence a real-time dashboard. Lancet 7500:2019-2020. https://doi.org/10.1016/ S2589-7500(20)30086-8

74. Cao B, Wang Y, Wen D, Liu W, Wang J, Fan G, Ruan L, Song B, Cai Y, Wei M, Li X, Xia J, Chen N, Xiang J, Yu T, Bai T, Xie X, Zhang L, Li C, Yuan Y, Chen H, Li H, Huang H, Tu S, Gong F, Liu Y, Wei Y, Dong C, Zhou F, Gu X, Xu J, Liu Z, Zhang Y, Li H, Shang L, Wang K, Li K, Zhou X, Dong X, Qu Z, Lu S, Hu X, Ruan S, Luo S, Wu J, Peng L, Cheng F, Pan L, Zou J, Jia C, Wang J, Liu X, Wang S, Wu X, Ge Q, He J, Zhan H, Qiu F, Guo L, Huang C, Jaki T, Hayden FG, Horby PW, Zhang D, Wang C (2020) A trial of lopinavir-ritonavir in adults hospitalized with severe Covid-19. N Engl J Med 382:1787-1799. https://doi.org/10.1056/ NEJMoa2001282

75. Chen $\mathrm{C}$, Zhang $\mathrm{Y}$, Jianying $\mathrm{H}$ et al (2020) Favipiravir versus Arbidol for COVID-19: a randomized clinical trial. medRxiv. https://doi.org/10.1101/2020.03.17.20037432

76. Gautret P, Lagier J-C, Parola P et al (2020) Hydroxychloroquine and azithromycin as a treatment of COVID-19: results of an openlabel non-randomized clinical trial. Int J Antimicrob Agents: 105949. https://doi.org/10.1016/j.ijantimicag.2020.105949

77. Cortegiani A, Ingoglia G, Ippolito M, Giarratano A, Einav S (2020) A systematic review on the efficacy and safety of chloroquine for the treatment of COVID-19. J Crit Care. https://doi.org/10.1016/j. jerc.2020.03.005

78. Savarino A, Boelaert JR, Cassone A et al (2003) Personal view antiviral effects of chloroquine effects of chloroquine on viral infections : an old drug against today' s diseases ? Personal view 3: $722-727$ 
79. Principi N, Esposito S (2020) Correspondence Chloroquine or hydroxychloroquine for prophylaxis of COVID-19. Lancet Infect Dis 3099:30296. https://doi.org/10.1016/S1473-3099(20)30296-6

80. Yao X, Ye F, Zhang M, Cui C, Huang B, Niu P, Liu X, Zhao L, Dong E, Song C, Zhan S, Lu R, Li H, Tan W, Liu D (2020) In vitro antiviral activity and projection of optimized dosing design of hydroxychloroquine for the treatment of severe acute respiratory syndrome coronavirus 2 (SARS-CoV-2). Clin Infect Dis an Off Publ Infect Dis Soc Am. https://doi.org/10.1093/cid/ciaa237

81. Finbloom DS, Silver K, Newsome DA, Gunkel R (1985) Comparison of hydroxychloroquine and chloroquine use and the development of retinal toxicity. J Rheumatol 12:692-694

82. Sahraei Z, Shabani M, Shokouhi S, Saffaei A (2020) Aminoquinolines against coronavirus disease 2019 (COVID-19): chloroquine or hydroxychloroquine. Int J Antimicrob Agents 55: 105945. https://doi.org/10.1016/j.ijantimicag.2020.105945

83. Liu J, Cao R, Xu M, Wang X, Zhang H, Hu H, Li Y, Hu Z, Zhong W, Wang M (2020) Hydroxychloroquine, a less toxic derivative of chloroquine, is effective in inhibiting SARS-CoV-2 infection in vitro. Cell Discov:6-9. https://doi.org/10.1038/s41421-0200156-0

84. Ohkuma S, Poole B (1981) Cytoplasmic vacuolation of mouse peritoneal macrophages and the uptake into lysosomes of weakly basic substances. J Cell Biol 90:656-664. https://doi.org/10.1083/ jcb.90.3.656

85. Hasan R, Rink L, Haase H (2016) Chelation of free $\mathrm{Zn}(2)(+)$ impairs chemotaxis, phagocytosis, oxidative burst, degranulation, and cytokine production by neutrophil granulocytes. Biol Trace Elem Res 171:79-88. https://doi.org/10.1007/s12011-015-0515-0

86. Prasad AS (2008) Zinc in human health: effect of zinc on immune cells. Mol Med 14:353-357. https://doi.org/10.2119/2008-00033. Prasad

87. Haase H, Rink L (2014) Zinc signals and immune function. Biofactors 40:27-40. https://doi.org/10.1002/biof.1114

88. Bonaventura P, Benedetti G, Albarede F, Miossec P (2015) Zinc and its role in immunity and inflammation. Autoimmun Rev 14: 277-285. https://doi.org/10.1016/j.autrev.2014.11.008
89. Rahman MT, Karim MM (2018) Metallothionein: a potential link in the regulation of zinc in nutritional immunity. Biol Trace Elem Res 182:1-13. https://doi.org/10.1007/s12011-017-1061-8

90. Solomon VR, Lee H (2009) Chloroquine and its analogs: a new promise of an old drug for effective and safe cancer therapies. Eur J Pharmacol 625:220-233. https://doi.org/10.1016/j.ejphar.2009.06. 063

91. Mizushima N, Yoshimori T, Levine B (2010) Methods in mammalian autophagy research. Cell 140:313-326. https://doi.org/10. 1016/j.cell.2010.01.028

92. Xue J, Moyer A, Peng B, Wu J, Hannafon BN, Ding WQ (2014) Chloroquine is a zinc ionophore. PLoS One 9:e109180. https://doi. org/10.1371/journal.pone.0109180

93. Denison MR, Perlman S (1986) Translation and processing of mouse hepatitis virus virion RNA in a cell-free system. J Virol 60:12-18

94. Denison MR, Zoltick PW, Hughes SA, Giangreco B, Olson AL, Perlman S, Leibowitz JL, Weiss SR (1992) Intracellular processing of the N-terminal ORF 1a proteins of the coronavirus MHV-A59 requires multiple proteolytic events. Virology 189:274-284. https:// doi.org/10.1016/0042-6822(92)90703-r

95. Ko W-S, Guo C-H, Hsu G-SW, Chiou YL, Yeh MS, Yaun SR (2005) The effect of zinc supplementation on the treatment of chronic hepatitis $\mathrm{C}$ patients with interferon and ribavirin. Clin Biochem 38:614-620. https://doi.org/10.1016/j.clinbiochem.2005. 04.003

96. Suzuki H, Takagi H, Sohara N, Kanda D, Kakizaki S, Sato K, Mori M, Gunma Liver Study Group (2006) Triple therapy of interferon and ribavirin with zinc supplementation for patients with chronic hepatitis C: a randomized controlled clinical trial. World J Gastroenterol 12:1265-1269. https://doi.org/10.3748/wjg.v12.i8. 1265

97. Saper RB, Rash R (2009) Zinc: an essential micronutrient. Am Fam Physician 79:768-772

Publisher's Note Springer Nature remains neutral with regard to jurisdictional claims in published maps and institutional affiliations. 